\title{
Apatite Chlorine Concentration Measurements by LA-ICP-MS
}

\author{
David M. Chew (1)*, Ray A. Donelick (2), Margaret B. Donelick (2), Balz S. Kamber (1) \\ and Michael J. Stock (3) \\ (1) Department of Geology, School of Natural Sciences, Trinity College Dublin, College Green, Dublin 2, Ireland \\ (2) Apatite to Zircon, Inc., 1075 Matson Road, Viola, ID, 83872-9709, USA \\ (3) Department of Earth Sciences, University of Oxford, South Parks Road, Oxford, OXI 3AN, UK \\ * Corresponding author. e-mail: chewd@tcd.ie
}

Apatite incorporates variable and significant amounts of halogens (mainly $\mathrm{F}$ and $\mathrm{Cl}$ ) in its crystal structure, which can be used to determine the initial $\mathrm{F}$ and $\mathrm{Cl}$ concentrations of magmas. The amount of chlorine in the apatite lattice also exerts an important compositional control on the degree of fission-track annealing. Chlorine measurements in apatite have conventionally required electron probe microanalysis (EPMA). Laser ablation inductively coupled plasma-mass spectrometry (LA-ICP-MS) is increasingly used in apatite fission-track dating to determine $U$ concentrations and also in simultaneous $\mathrm{U}-\mathrm{Pb}$ dating and trace element measurements of apatite. Apatite $\mathrm{Cl}$ measurements by ICP-MS would remove the need for EPMA but the high (12.97 eV) first ionisation potential makes analysis challenging. Apatite $\mathrm{Cl}$ data were acquired using two analytical set-ups: a Resonetics M-50 193 nm ArF Excimer laser coupled to an Agilent $7700 \times$ quadrupole ICP-MS (using a $26 \mu \mathrm{m}$ spot with an $8 \mathrm{~Hz}$ repetition rate) and a Photon Machines Analyte Excite $193 \mathrm{~nm}$ Arf Excimer laser coupled to a Thermo Scientific iCAP Qc (using a $30 \mu \mathrm{m}$ spot with a $4 \mathrm{~Hz}$ repetition rate). Chlorine concentrations were determined by LA-ICP-MS ( 1140 analyses in total) for nineteen apatite occurrences, and there is a comprehensive EPMA $\mathrm{Cl}$ and $\mathrm{F}$ data set for 13 of the apatite samples. The apatite sample suite includes different compositions representative of the range likely to be encountered in natural apatites, along with extreme variants including two end-member chlorapatites. Between twenty-six and thirty-nine isotopes were determined in each apatite sample corresponding to a typical analytical protocol for integrated apatite fission track ( $U$ and $\mathrm{Cl}$ contents) and $\mathrm{U}-\mathrm{Pb}$ dating, along with REE and trace element measurements. ${ }^{35} \mathrm{Cl}$ backgrounds (present mainly in the argon gas) were $\sim 45-65 \mathrm{kcps}$ in the first set-up and $\sim 4 \mathrm{kcps}$ in the second set-up. ${ }^{35} \mathrm{Cl}$ background-corrected signals ranged from $\sim 0 \mathrm{cps}$ in end-member fluorapatite to up to $\sim 90 \mathrm{kcps}$ in end-member chlorapatite. Use of a collision cell in both analytical set-ups decreased the low mass
L'apatite contient des quantités variables et significatives $d^{\prime}$ halogènes (notamment $\mathrm{F}$ et $\mathrm{Cl}$ ) dans sa structure cristalline qui peuvent être utilisées pour déterminer la concentration initiale en $\mathrm{F}$ et $\mathrm{Cl}$ des magmas. La quantité de chlore dans le réseau de l'apatite exerce également un contrôle compositionnel important sur le degré de recuit des traces de fission. Les mesures du chlore dans l'apatite ont conventionnellement nécessité la microanalyse par sonde électronique (EPMA). La spectrométrie de masse à source plasma couplée à l'ablation laser (LAICP-MS) est de plus en plus utilisé dans la datation sur traces de fission de l'apatite pour déterminer les concentrations en $U$ et aussi pour la datation simultanées $\mathrm{U}-\mathrm{Pb}$ et les mesures des éléments traces de l'apatite. Les mesures du Cl dans l'apatite par ICP-MS élimineraient la nécessité d'utiliser l'EPMA mais le fait que le premier potentiel d'ionisation (12.97 eV) soit haut rend l'analyse difficile. Les données du Cl dans l'apatite ont été acquises au moyen de deux systèmes analytiques: un laser ArF excimer $193 \mathrm{~nm}$ Resonetics M-50 couplé à un ICP-MS quadripôle Agilent 7700× (utilisant un spot de $26 \mu \mathrm{m}$ avec un taux de répétition de $8 \mathrm{~Hz}$ ) et un laser ArF excimer 193 nm Photon Machines Analyte Excite couplé à un Thermo Scientific iCAP Qc (en utilisant un spot $30 \mu \mathrm{m}$ avec un taux de répétition de $4 \mathrm{~Hz}$ ). Les concentrations en chlore ont été déterminées par LA-ICPMS (1 140 analyses au total) pour dix-neuf occurrences d'apatite, et il y a une complète base de données EPMA pour le $\mathrm{Cl}$ et le $\mathrm{F}$ pour treize des échantillons d'apatite. La suite comprend différents échantillons d'apatite représentant la gamme de compositions susceptible d'être rencontré dans les apatites naturelles, ainsi que des variantes extrêmes dont deux endmembers chlorapatites. Entre vingt-six et trente-neuf isotopes ont été déterminés dans chaque échantillon d'apatite ce qui correspond à un protocole classique d'analyse intégrée des traces de fission (teneurs en $\mathrm{U}$ et $\mathrm{Cl}$ ) et datation U-Pb sur apatite, avec les mesures des REE et des éléments traces. Les bruits de fond $d v{ }^{35} \mathrm{Cl}$ (surtout présent dans le gaz argon) 
sensitivity by approximately an order of magnitude without improving the ${ }^{35} \mathrm{Cl}$ signal-to-background ratio. A minor $\mathrm{Ca}$ isotope was used as the internal standard to correct for drift in instrument sensitivity and variations in ablation volume during sessions. The ${ }^{35} \mathrm{Cl} /{ }^{43} \mathrm{Ca}$ values for each apatite (10-20 analyses each) when plotted against the EPMA Cl concentrations yield excellently constrained calibration relationships, demonstrating the suitability of the analytical protocol and that routine apatite $\mathrm{Cl}$ measurements by ICP-MS are achievable.

Keywords: apatite, LA-ICP-MS, chlorine, fission track, annealing. étaient d'environ 45-65 kcps pour le premier système $d^{\prime}$ 'analyse et d'environ 4 kcps pour le second système. Le signal corrigé du bruit de fond pour ${ }^{35} \mathrm{Cl}$ varie de $\sim 0$ cps dans l'endmember fluorapatite jusqu'à environ 90 kcps pour l'endmember chlorapatite. L'utilisation d'une cellule de collision avec les deux types de systèmes d'analyse a diminué la sensibilité des faibles masses d'environ un ordre de grandeur sans pour autant améliorer le rapport signal-bruit de fond $d u{ }^{35} \mathrm{Cl}$. Un isotope mineur du Ca a été utilisé comme étalon interne pour corriger la dérive de sensibilité de l'instrument et les variations du volume d'ablation au cours des séances d'analyse. Les valeurs ${ }^{35} \mathrm{Cl} /{ }^{43} \mathrm{Ca}$ pour chaque apatite (10-20 analyses chacune) lorsqu'elles sont reportées par rapport aux concentrations en $\mathrm{Cl}$ obtenu par EPMA produisent des relations d'étalonnage parfaitement contraintes, ce qui démontre la pertinence du protocole analytique et que les mesures de routine du Cl de l'apatite par ICP-MS sont réalisables.

Mots-clés : apatite, LA-ICP-MS, chlore, traces de fission, recuit.
Apatite is a common accessory mineral in igneous, metamorphic and clastic sedimentary rocks. Apatite can be described by the general formula $A_{5}\left(X_{4}\right)_{3} Z$ (e.g., Sommeraver and Katz-Lehnert 1985, Piccoli and Candela 2002). The A-site accommodates large cations (e.g., $\mathrm{Ca}^{2+}, \mathrm{Sr}^{2+}$, $\left.\mathrm{Pb}^{2+}, \mathrm{Ba}^{2+}, \mathrm{Mg}^{2+}, \mathrm{Mn}^{2+}, \mathrm{Fe}^{2+}, \mathrm{REE}^{3+}, \mathrm{Eu}^{2+}, \mathrm{Cd}^{2+}, \mathrm{Na}^{+}\right)$in two sites that exhibit Vll-fold ( $\mathrm{Ca} 2$ ) and ninefold (Cal) coordination, respectively. The $\mathrm{X}$-site, occupied primarily by $\mathrm{P}^{5+}$ (as $\mathrm{PO}_{4}{ }^{3+}$ ), exhibits fourfold coordination and can accommodate other small highly charged cations (e.g., $\mathrm{Si}^{4+}$, $\left.\mathrm{S}^{6+}, \mathrm{As}^{5+}, \mathrm{V}^{5+}\right)$. The Z-site is occupied by the halogens $\mathrm{F}^{-}$and $\mathrm{Cl}^{-}$, as well as $\mathrm{OH}^{-}$, which correspond to an isomorphous series with fluorapatite, chlorapatite and hydroxylapatite end members, respectively. Of these, fluorapatite is by far the commonest, and the term 'apatite' is sometime used synonymously with fluorapatite.

Apatite can incorporate a significant amount of halogens (mainly $\mathrm{F}$ and $\mathrm{Cl}$ ) and $\mathrm{OH}^{-}$in its crystal structure, which has shown to be useful to determine both the fugacity ratios and the initial $\mathrm{F}$ and $\mathrm{Cl}$ concentrations of magmas (Piccoli and Candela 1994), the volatile budget of lunar magmatic rocks (e.g., Boyce et al. 2010) and mantle apatite (O'Reilly and Griffin 2000). In most magmatic rocks, the fluorapatite component dominates over chlorapatite and hydroxylapatite (e.g., Piccoli and Candela 2002). In addition to providing information on the volatile budget of magmas, the halogen content of apatite (and in particular its chlorine content) exercises an important control on the annealing behaviour of fission tracks in apatite (Donelick 1993, Carlson et al. 1999, Barbarand et al. 2003), a low-temperature thermochronometer which yields thermal history information in the 60-110 ${ }^{\circ} \mathrm{C}$ temperature window (Laslett et al. 1987).

LA-ICP-MS is increasingly used in apatite fission-track dating to determine $U$ concentrations (Hasebe et al. 2004), increasing the speed of analysis and eliminating neutron irradiation, and also in simultaneous U-Pb dating of apatite, a method that yields high-temperature $\left(\sim 500-400{ }^{\circ} \mathrm{C}\right)$ apatite cooling ages. Other chemical data (trace elements, REE) can also be determined with this integrated analytical protocol (e.g., Chew and Donelick 2012). Simultaneous measurement of chlorine would allow for characterisation of the thermal annealing kinetics of fission tracks in apatite and would remove the need for additional analyses by electron microprobe. This study assesses the possibility of routine LAICP-MS measurements of chlorine in apatite, an anion which is difficult to analyse by ICP-MS due to its high first ionisation potential.

Determination of $\mathrm{Cl}$ and $\mathrm{F}$ in apatite has typically been undertaken by electron probe microanalysis (EPMA). The minor hydroxylapatite component is usually calculated by stoichiometry assuming a full Z-site as $\mathrm{H}$ cannot be directly 


\section{GEOSTANDARDS and GEOANALYTICAL \\ RESEARCH}

determined by EPMA. Difficulties with $\mathrm{F}$ and $\mathrm{Cl}$ concentration measurements by EPMA include beam-induced sample damage and temporal variation of $\mathrm{F}$ and $\mathrm{Cl} \mathrm{X}$-rays. Both effects are mainly dependent on beam current, beam spot size and apatite orientation (Stormer et al. 1993). Systematically high apparent $F$ concentrations and non-linear variations in $\mathrm{F}$ and $\mathrm{Cl}$ X-ray intensities can be avoided by orientating the electron beam perpendicular to the apatite c-axis and using $a \leq 15 \mathrm{nA}$ beam current with $a \geq 5 \mu \mathrm{m}$ diameter defocused beam (Henderson 2011).

Marks et al. (2012) investigated volatile concentrations $(\mathrm{F}, \mathrm{Cl}, \mathrm{Br}, \mathrm{S}$ and $\mathrm{C})$ in magmatic apatite using a variety of analytical methods. They analysed fluorapatite (Durango, Mexico), chlorapatite (Ødegården, Norway) and apatites from five plutonic samples from the alkaline Mt. Saint Hilaire Complex (Canada) by EPMA, laser ablation inductively coupled plasma-mass spectrometry (LA-ICP-MS), secondary ion mass spectrometry (SIMS), pyrohydrolysis combined with ion chromatography, Fourier transformed infrared spectroscopy (FTIR), instrumental neutron activation analysis (INAA) and total reflection $\mathrm{X}$-ray fluorescence analysis (TXRF). Their comprehensive study demonstrated that total reflection $X$-ray fluorescence analysis is well suited to simultaneously analysing trace metals (e.g., $\mathrm{Sr}, \mathrm{Ce}, \mathrm{Fe}, \mathrm{Mn}, \mathrm{As}$ ) as well as $\mathrm{Br}$ in the low- to sub- $\mu \mathrm{g} \mathrm{g}^{-1}$ concentration range in natural apatites. However, bulk samples (a few mg of sample powder) are required and low atomic number elements such as $\mathrm{F}$ or $\mathrm{C}$ cannot be determined with this method. If spatial resolution is required, the ICP-MS or SIMS methods are more appropriate alternatives.

\section{The role of chlorine on the annealing behaviour of fission tracks in apatite}

Fission-track dating is a widely used technique for reconstructing the low-temperature thermal histories of upper crustal rocks. It has been used to investigate the tectonic and thermal histories of compressional and extensional margins, the stability of continental interiors, the thermal histories of sedimentary basins and in landscape evolution studies. The method has been described and reviewed elsewhere (e.g., Gleadow and Duddy 1981, Gleadow et al. 1986a, b, Gallagher et al. 1998, Donelick et al. 2005), and this section only presents a brief overview of the technique. Fission-track dating is based on the spontaneous fission decay of ${ }^{238} U$ which produces linear defects, referred to as fission tracks, in the lattice of uranium-bearing minerals (Price and Walker 1963, Fleischer et al. 1975). For analysis, fission tracks are enlarged using a standardised chemical etching process so they can be observed under an optical microscope (Price and Walker 1962). The technique is widely applied to apatite, zircon and titanite because they contain sufficient $U$ (typically $>10 \mu \mathrm{g} \mathrm{g}^{-1}$ ) to generate a statistically useful quantity of spontaneous fission tracks over geological time. By comparing the density of fission tracks with the $U$ content of the mineral, an apparent fission-track age can be calculated. A fission-track age provides an estimate of the time that has elapsed as the mineral cooled through a specific temperature window (the partial annealing zone or PAZ). The apatite PAZ is estimated at 60 $110^{\circ} \mathrm{C}$ although this varies with apatite composition (Green et al. 1986, Carlson et al. 1999, Barbarand et al. 2003). At temperatures higher than the PAZ, fission tracks are completely annealed (or removed) via thermally activated diffusion of the relocated ionic species in the lattice. At temperatures lower than the PAZ, there is insufficient energy to cause significant repair of fission tracks.

The annealing behaviour of fission tracks in apatite is not completely understood, but it is known to be highly temperature dependent and moderately dependent upon crystallographic orientation. It is also dependent on the chemical composition and crystal structure of the host apatite, with apatites richer in fluorine being more easily annealed than those richer in chlorine (e.g., Green et al. 1985, Carlson et al. 1999, Barbarand et al. 2003). Fissiontrack annealing models attempt to correlate fission-track annealing kinetics with measurable parameters, commonly referred to as kinetic parameters, which take into account these variations in the chemical composition or etching characteristics of the host apatite (e.g., Donelick 1993, Carlson et al. 1999, Barbarand et al. 2003). These kinetic parameters include Dpar, the fission-track etch figure diameter parallel to the crystallographic c-axis and the apatite chlorine content.

\section{Apatite samples}

Chlorine concentrations for nineteen apatite occurrences were determined by ICP-MS (Table 1). Nine of the specimens analysed (those marked with an asterisk in Table 1) were those employed in the study of Carlson et al. (1999), which investigated apatite fission-track annealing rates as a function of composition. In addition to having a comprehensive suite of EPMA data (including $\mathrm{Cl}$ ), the Carlson et al. (1999) data set has the advantage of including several different compositions representative of the range likely to be encountered in natural apatites along with several extreme compositional variants. Several apatite U-Pb age reference materials were also analysed, including Madagascar apatite (sample MAD; individual fragments range from 475485 Ma; Thomson et al. 2012), McClure Mountain syenite apatite (sample MM; $523.51 \pm 2.09$ Ma, Schoene and 


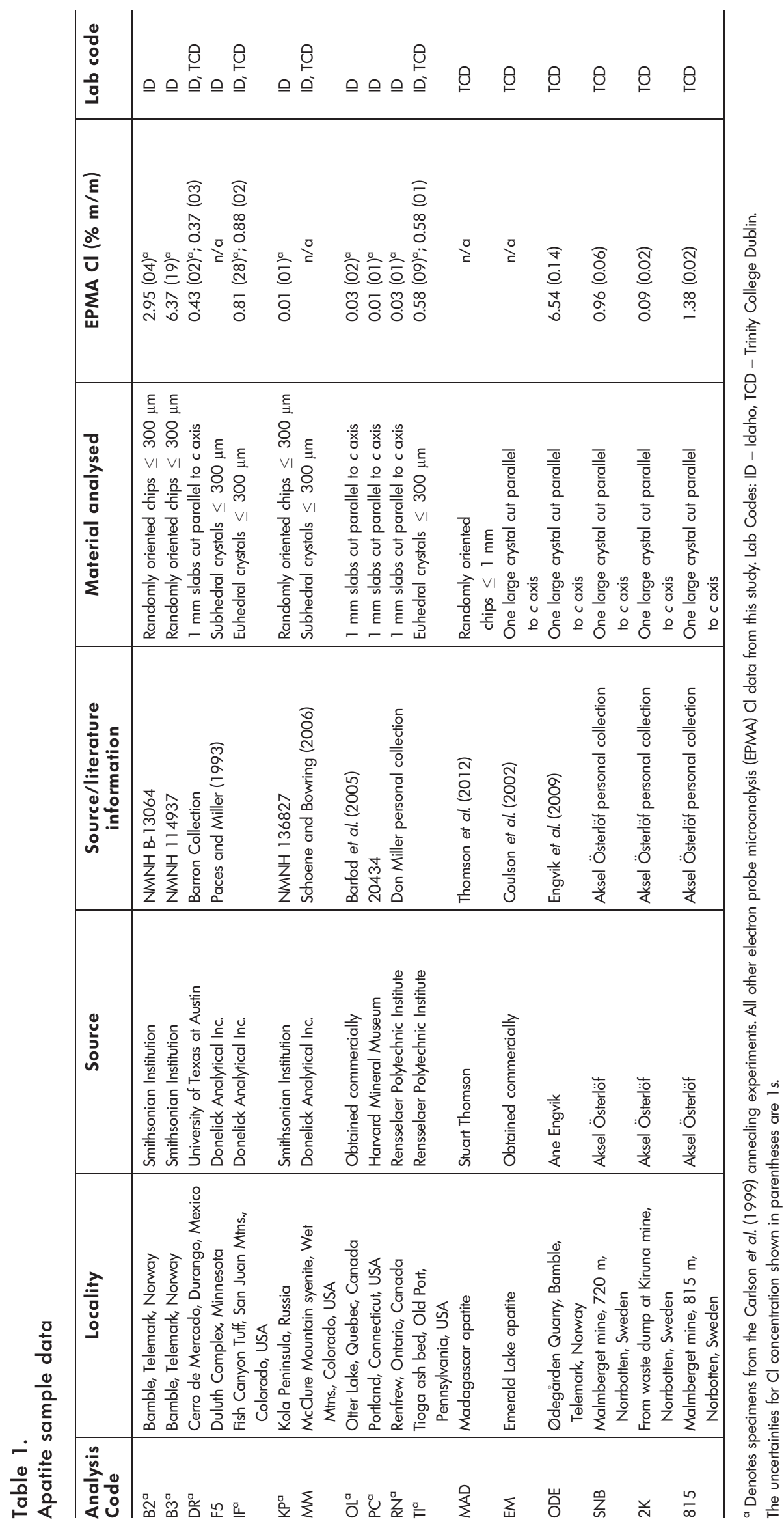




\section{GEOSTANDARDS and GEOANALYTICAL}

Bowring 2006), Duluth Complex apatite (sample F5; zircon age of $1099.1 \pm 0.2 \mathrm{Ma}$, Schmitz et al. 2003) and Emerald Lake apatite (sample EM, $92.5 \pm 3.3 \mathrm{Ma}$; Chew et al. $2011)$. Three samples $(2 K, S N B, 815)$ from the Malmberget iron ore mine in Norrbotten, Sweden, and an additional chlorapatite sample (ODE) from Ødegården Quarry, Bamble, Nonway, from the study of Engvik et al. (2009) were also analysed. All three apatites with appreciable chlorine contents in this study, including samples B2 and B3 of Carlson et al. (1999), come from the Bamble region.

The apatites were obtained in the form of euhedral megacrysts, fragments of megacrysts or a collection of small euhedral to subhedral crystals. Megacrysts with a welldeveloped prismatic crystal face were cut into $1 \mathrm{~mm}$ thick slabs parallel to their crystallographic c-axes using a diamond wafering saw. Fragments of megacrysts that did not exhibit well-developed crystal faces were crushed using a mortar and pestle, then sieved to obtain randomly oriented fragments of $<300 \mu \mathrm{m}$ maximum diameter. This ensured that no crystallographic orientation was preferentially sampled when analysing the megacryst fragments. Collections of euhedral and subhedral grains with maximum diameters $<300 \mu \mathrm{m}$ were obtained from bulk rock samples using standard gravimetric and magnetic mineral separation methods.

\section{Analytical method}

The major issue in the precise and accurate determination of chlorine by LA-ICP-MS is its high first ionisation potential (12.97 eV) which is close to that of the $\mathrm{Ar}$ $(15.76 \mathrm{eV})$ plasma resulting in relatively low sensitivities. This issue also affects other anions with high first ionisation potentials (e.g., S: $10.36 \mathrm{eV}$ and $\mathrm{Br}: 11.81 \mathrm{eV}$ ). A second problem is the high background signals on the two principal stable chlorine isotopes $\left({ }^{35} \mathrm{Cl}\right.$ and $\left.{ }^{37} \mathrm{Cl}\right)$. In particular, polyatomic isobaric interferences on ${ }^{37} \mathrm{Cl}^{+}$from hydrides $\left({ }^{36} \mathrm{ArH}^{+}\right)$are a major problem in determining stable chlorine isotope ratios (Fietzke et al. 2008), with the amount of hydride generation closely correlated with the plasma core temperature and the Ar nebuliser gas flow. Polyatomic isobaric interferences in ICP-MS can be reduced by the use of collision or reaction cells (e.g., Tanner et al. 2002) but often with a trade-off of decreased sensitivity, particularly for the low-mass end of the periodic table.

In this study, apatite $\mathrm{Cl}$ data were acquired using two separate analytical set-ups: a Resonetics M-50 193 nm ArF Excimer laser ablation system coupled to an Agilent 7700x quadrupole ICP-MS at the Donelick Properties laboratory in Viola, Idaho, USA (sessions a-f, Table 2), and a Photon Machines Analyte Excite 193 nm ArF Excimer laser ablation system coupled to a Thermo Scientific iCAP Qc at the Department of Geology, Trinity College Dublin, Ireland (sessions $g-h$, Table 2). The two systems are referred to hereafter as the Idaho and Dublin analytical set-ups, respectively. The acquisition parameters of all analytical sessions are listed in Table 2, with differences in the analytical conditions between sessions highlighted in italics. Between twenty-six and thirty-nine isotopes were determined in each apatite sample (Table 2), corresponding to a typical analytical protocol for integrated apatite fission-track and U$\mathrm{Pb}$ dating (Chew and Donelick 2012). Of these isotopes, ${ }^{43} \mathrm{Ca}$ or ${ }^{44} \mathrm{Ca}$ was used as the internal standard to correct for drift in instrument sensitivity and variations in ablation volume during sessions. Common trace elements in apatite and the REE were determined along with seven isotopes ${ }^{200} \mathrm{Hg}, \quad 204,206,207,208 \mathrm{~Pb},{ }^{232} \mathrm{Th}$ and $\left.{ }^{238} \mathrm{U}\right)$ commonly required for $\mathrm{U}-\mathrm{Th}-\mathrm{Pb}$ geochronology.

Data reduction was undertaken using the trace elements' data reduction scheme of the freeware IOLITE package of Paton et al. (2011). The IOLITE approach involves processing an entire analytical session of data, which is not only more efficient but also greatly improves the consistency and reliability of data reduction. User-defined time intervals were established for the baseline-correction procedure to calculate session-wide baseline-corrected values for each isotope. In this study, the time intervals for the baseline correction for each isotope ranged from 10 to $15 \mathrm{~s}$. These time intervals were defined by selecting portions of the signal in between apatite analyses which exhibited local minima for the internal elemental standard, either ${ }^{43} \mathrm{Ca}$ (sessions $\mathrm{a}-\mathrm{g}$ ) or ${ }^{44} \mathrm{Ca}$ (session $\mathrm{h}$ ). The ${ }^{35} \mathrm{Cl}$ backgroundcorrected signals for each apatite analysis were then normalised to the internal standard (Table 2).

Apatite major element $(\mathrm{Cl}, \mathrm{F}, \mathrm{P}, \mathrm{Ca})$ compositions were determined for seven samples (DR, IF, TI, ODE, 2K, 815, SNB) using a wavelength-dispersive Jeol 8600 electron microprobe at the Research Laboratory for Archaeology and the History of Art, University of Oxford. An accelerating voltage of $15 \mathrm{kV}$ and defocused (10 $\mu \mathrm{m}$ diameter) beam were used to minimise the halogen migration effects reported by Stormer et al. (1993). For consistency and to obtain sufficient counts rates for accurate determination of $\mathrm{Cl}$ concentrations in the F-rich apatite samples, a $15 \mathrm{nA}$ beam current was used for all analyses. Count times were $60 \mathrm{~s}$ (on-peak) for all elements. The instrument was calibrated using a suite of appropriate mineral and synthetic reference materials, under the same beam conditions used for sample analyses. The Durango apatite is commonly used as a secondary reference material in EPMA and the validity of the instrument calibration was confirmed by the agreement between the 


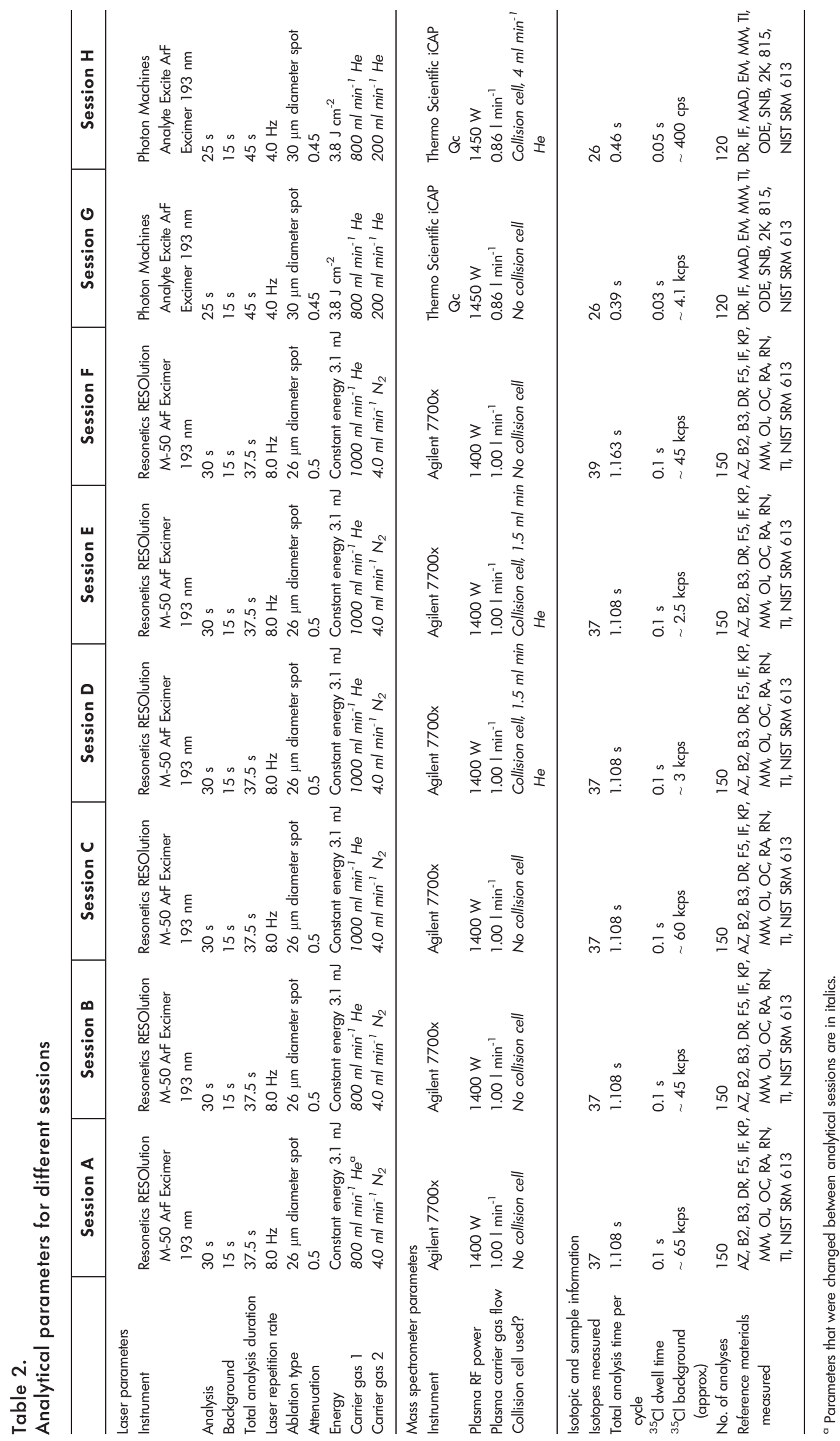




\section{GEOSTANDARDS and GEOANALYTICAL \\ RESEARCH}

concentrations of major elements in sample DR obtained in this study and in the published results of Carlson et al. (1999). The $\mathrm{Cl}$ content of the apatite samples, determined by EPMA, is summarised in Table 1.

\section{Results}

All analytical data ( 1140 individual apatite Cl analyses) are listed in the supplementary data table (Table A1) and summarised in Table 3. Nine hundred individual apatite $\mathrm{Cl}$ analyses spread over six separate analytical sessions were undertaken using the Idaho set-up (Tables 2 and 3, Figure $1 \mathrm{a}-\mathrm{f}$ ), and 240 individual apatite $\mathrm{Cl}$ analyses spread over two separate analytical sessions were undertaken using the Dublin set-up (Tables 2 and 3, Figure $1 \mathrm{~g}-\mathrm{h}$ ).

The Idaho analytical set-up employed a $26 \mu \mathrm{m}$ spot and an $8 \mathrm{~Hz}$ laser repetition rate (Table 2). Nine apatites from the Carlson et al. (1999) annealing experiments for which there are EPMA Cl data (Table 1) were analysed (B2, B3, DR, IF, KP, OL, PC, RN and TI) along with four apatites for which no EPMA data are presently available (AZ, F5, MM and RA). Each of the six analytical sessions consisted of cycling ten times through the entire suite of thirteen apatites. This yielded 150 analyses in total as the apatite U-Pb age reference materials; MM and F5 were analysed twice per cycle. ${ }^{35} \mathrm{Cl}$ backgrounds for the Idaho analytical set-up ranged from 45-65 kcps in standard mode (Table 2, sessions a, b, c and f) and from $\sim 2.5-3 \mathrm{kcps}$ (Table 2, sessions $d$ and e) using the collision cell (the Agilent Octopole Reaction System in He Mode). The ${ }^{35} \mathrm{Cl}$ backgrounds in both set-ups typically exhibited a sinusoidal time-resolved signal intensity, with a periodicity of $\sim 40 \mathrm{~min}$ and an amplitude of $20 \%$ of the mean ${ }^{35} \mathrm{Cl}$ background. This is attributed to periodic temperature fluctuations in both laboratories related to their air conditioning systems. ${ }^{35} \mathrm{Cl}$ background-corrected signals ranged from $\sim 0 \mathrm{cps}(\mathrm{OL}, \mathrm{PC}, \mathrm{MM})$ to $\sim 90 \mathrm{kcps}$ (B3) in standard mode, with the ${ }^{35} \mathrm{Cl}$ background-corrected signals of the B3 chlorapatite dropping to $\sim 4.5 \mathrm{kcps}$ using the collision cell (a twenty-fold drop in sensitivity).

The Dublin analytical set-up employed a $30 \mu \mathrm{m}$ spot and a $4 \mathrm{~Hz}$ laser repetition rate (Table 2). Seven apatites for which there were EPMA Cl data (Table 1) were analysed (DR, IF, TI, ODE, 2K, SNB and 815) along with three apatites for which no EPMA data were available (MM, EM and MAD). Both analytical sessions consisted of cycling twelve times through the entire suite of ten apatites yielding 120 analyses in total per session. ${ }^{35} \mathrm{Cl}$ backgrounds for the Dublin analytical set-up were $\sim 4.1 \mathrm{kcps}$ in standard mode (Table 2, session g) and $\sim 400 \mathrm{cps}$ (Table 2, session h) using the collision cell in Kinetic Energy Discrimination (KED) mode with helium as the collision cell gas. ${ }^{35} \mathrm{Cl}$ backgroundcorrected signals ranged from $\sim 200 \mathrm{cps}$ (MM) to $\sim 22 \mathrm{kcps}$ (ODE) in standard mode, with the ${ }^{35} \mathrm{Cl}$ background-corrected signals of the B3 chlorapatite dropping to $\sim 1.6$ kcps using the collision cell (a fourteen-fold drop in sensitivity).

The ${ }^{35} \mathrm{Cl}$ background-corrected signals were normalised to the internal standard $\left({ }^{43} \mathrm{Ca}\right.$ in sessions a-g and ${ }^{44} \mathrm{Ca}$ in session $\mathrm{h}$ ) to correct for variations in signal intensity during and between ablations. The ${ }^{35} \mathrm{Cl} /{ }^{43} \mathrm{Ca}$ (or ${ }^{35} \mathrm{Cl} /{ }^{44} \mathrm{Ca}$ ) values for each apatite were taken as the mean of ten analyses for each of B2, B3, DR, IF, OL, PC, RN and TI in sessions a-f (Idaho) and the mean of twelve analyses of ODE, 2K, SNB, 815, DR, IF and $\mathrm{TI}$ in sessions $\mathrm{g}-\mathrm{h}$ (Dublin). These ${ }^{35} \mathrm{Cl} /{ }^{43} \mathrm{Ca}$ (or ${ }^{35} \mathrm{Cl} /{ }^{44} \mathrm{Ca}$ ) values were plotted against the EPMA Cl concentrations for each analytical session (Figure la-h), with sessions a-f (ldaho) employing the EPMA Cl concentrations from the Carlson et al. (1999) data set and sessions $g-h$ (Dublin) using the EPMA Cl concentrations undertaken in this study (Table 1). The $R^{2}$ value for each regression in Figure 1 ( $a-h$ ) was $>0.99$ (and $>0.999$ for seven of the eight analytical sessions), implying an excellently constrained calibration. The dependence of the calibration relationships on the end-member chlorapatite samples is discussed later.

The four apatite samples in sessions a- $f$ (Idaho) for which no EPMA data were available at the time of analysis (AZ, F5, $M M$ and RA) yielded consistent chlorine concentration values within analytical uncertainty between LA-ICP-MS sessions. The calculated $\mathrm{Cl}$ concentration averages (in \% $\mathrm{m} / \mathrm{m}$ and uncertainties expressed as $2 \mathrm{~s}$ ) for sessions a- $f$ were $0.084 \pm 0.03$ (AZ), $0.58 \pm 0.14$ (F5), $-0.001 \pm 0.04$ $(M M)$ and $0.034 \pm 0.03(R A)$, respectively. The three apatite samples in sessions $g-h$ (Dublin) for which no EPMA data were available (MAD, MM and EM) also yielded chlorine concentration values within analytical uncertainty for both LAICP-MS sessions. The calculated $\mathrm{Cl}$ concentration averages (in $\% \mathrm{~m} / \mathrm{m}, \pm 2 \mathrm{~s}$ ) for sessions $\mathrm{g}-\mathrm{h}$ were $0.22 \pm 0.01$ (MAD), $0.06 \pm 0.01(\mathrm{MM})$ and $0.12 \pm 0.01$ (EM).

The detection limits for apatite $\mathrm{Cl}$ determinations by ICPMS could be assessed by examining the low $\mathrm{Cl}$ apatites $(<0.05 \% \mathrm{~m} / \mathrm{m} \mathrm{Cl})$ for which there were both EPMA and ICP-MS data. Using the ${ }^{35} \mathrm{Cl} /{ }^{43} \mathrm{Ca}$ versus EPMA Cl concentration relationships presented in Figure la-h for the Idaho set-up, samples OL (EPMA $0.03 \% \mathrm{~m} / \mathrm{m} \mathrm{Cl}$ ), PC (EPMA $0.01 \% \mathrm{~m} / \mathrm{m} \mathrm{Cl}$ ) and RN (EPMA $0.03 \% \mathrm{~m} / \mathrm{m} \mathrm{Cl}$ ) yielded calculated ICP-MS Cl concentration averages (in \% m/m) of $0.005 \pm 0.03(\mathrm{OL}$ ), $-0.03 \pm 0.04(\mathrm{PC}$ ) and $-0.02 \pm 0.03(\mathrm{RN})$, respectively ( $2 \mathrm{~s}$ uncertainties in all 


\begin{tabular}{|c|c|c|}
\hline & $\tilde{N}$ & 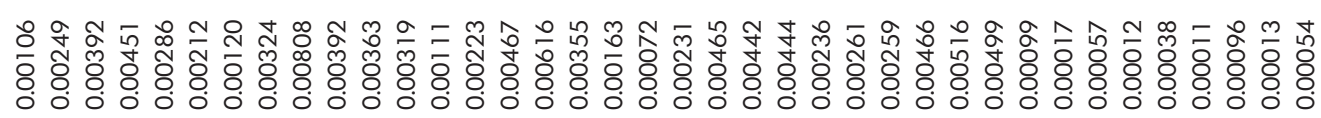 \\
\hline & 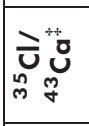 & 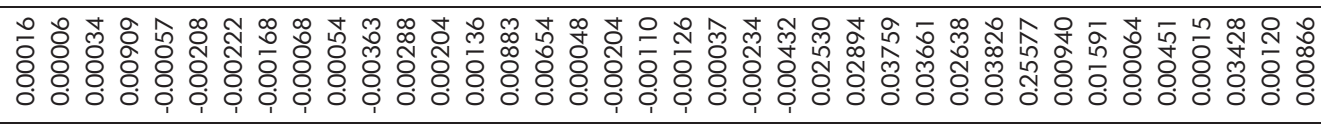 \\
\hline & $\tilde{n}$ & 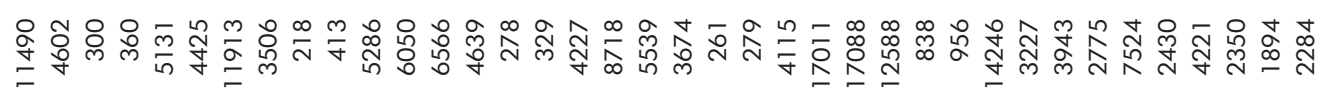 \\
\hline & 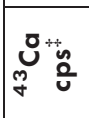 & 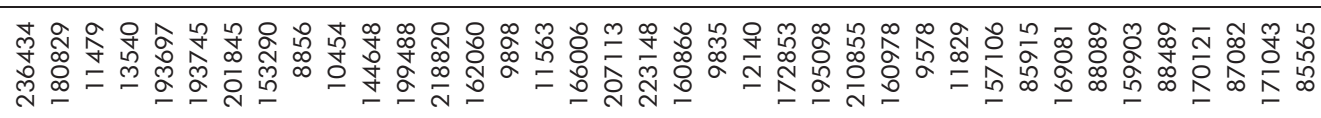 \\
\hline & 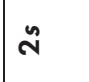 & 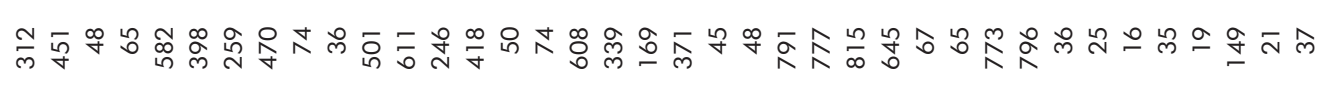 \\
\hline & $\overline{\bar{D}^{+}}$ & 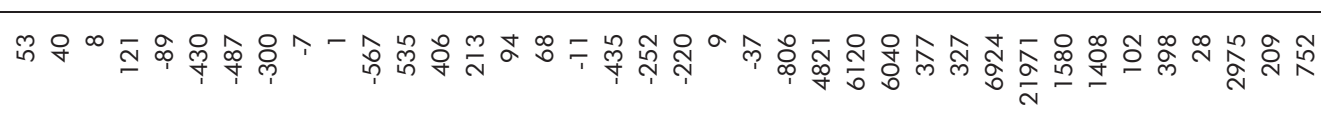 \\
\hline & $\tilde{N}$ & 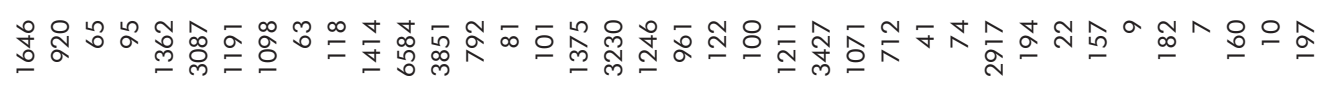 \\
\hline & 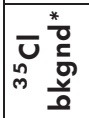 & 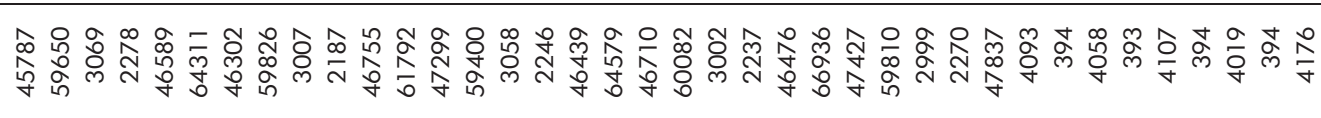 \\
\hline & $\frac{n}{n}$ & 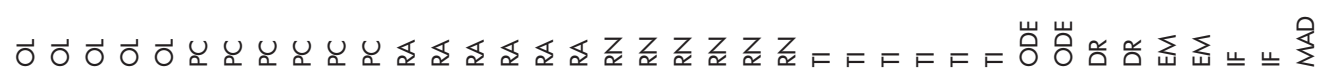 \\
\hline & $\stackrel{8}{\frac{0}{4}}$ & 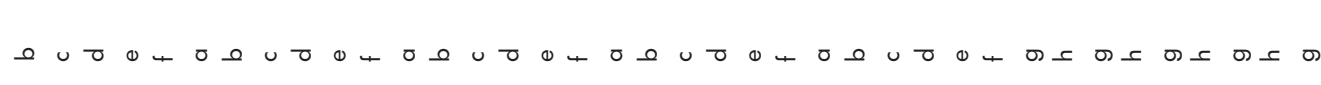 \\
\hline & $\tilde{N}$ & 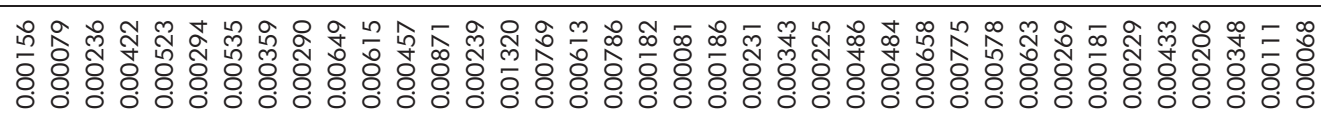 \\
\hline & 它 & 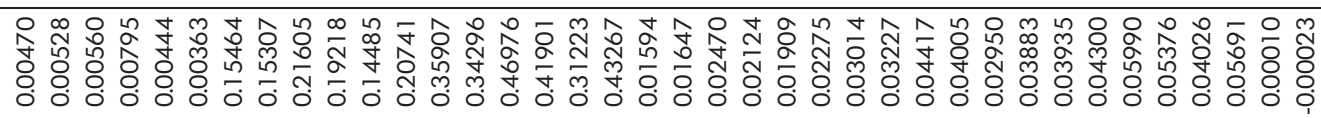 \\
\hline & $\tilde{N}$ & 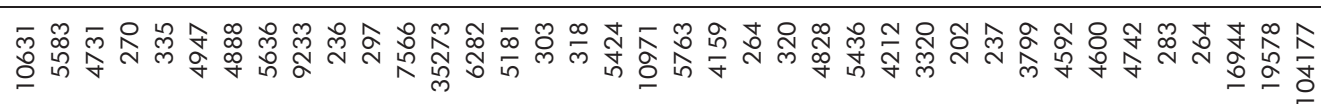 \\
\hline & 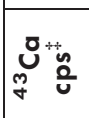 & 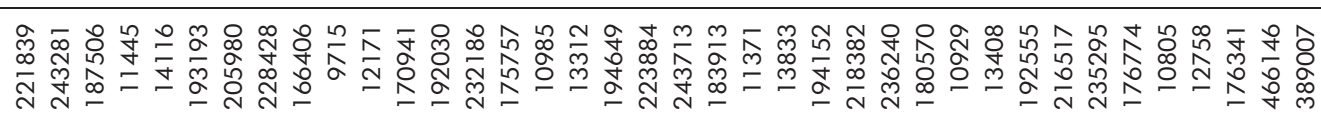 \\
\hline$\frac{0}{\frac{0}{0}}$ & $\tilde{N}$ & 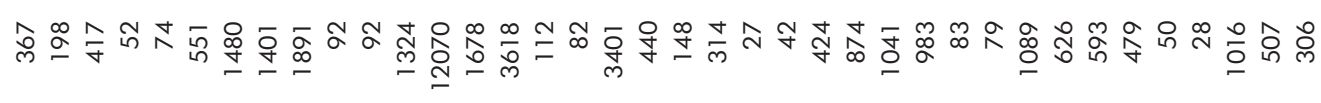 \\
\hline 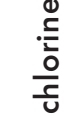 & $\bar{c}_{\infty}^{\infty}$ & 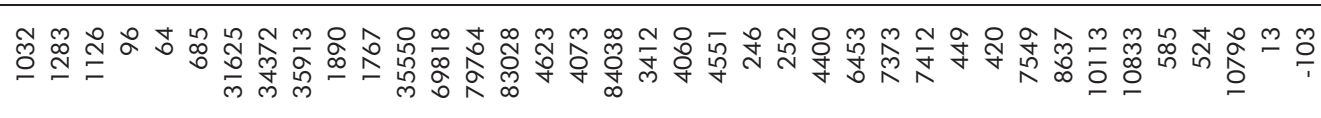 \\
\hline$\sum_{\substack{1 \\
U}}^{n}$ & $\stackrel{n}{n}$ & 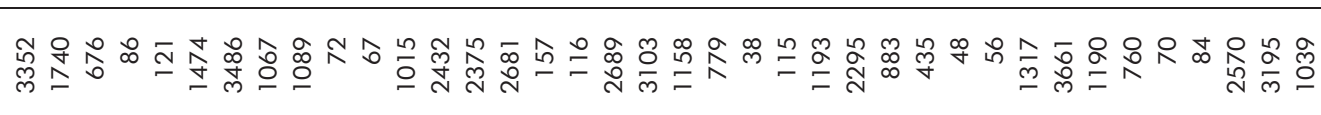 \\
\hline 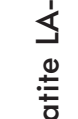 & 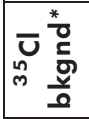 & 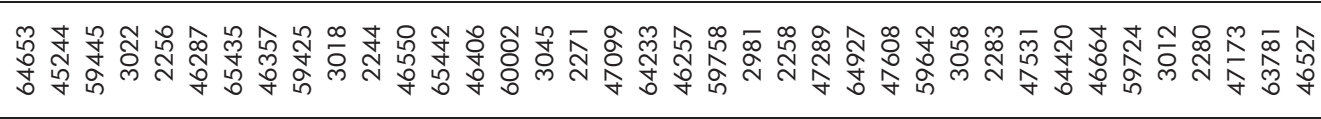 \\
\hline$\frac{0}{0}$ & & 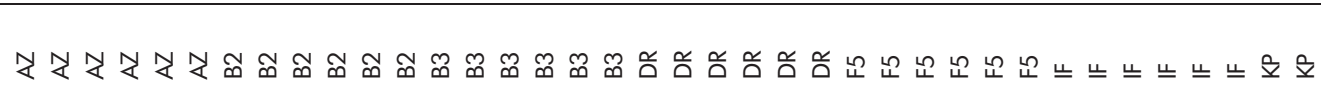 \\
\hline 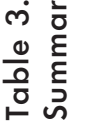 & $\begin{array}{l}\frac{n}{\mathrm{n}} \\
\frac{\mathrm{m}}{0} \\
\frac{\mathrm{e}}{<}\end{array}$ & \\
\hline
\end{tabular}




\section{GEOSTANDARDS and GEOANALYTICAL}

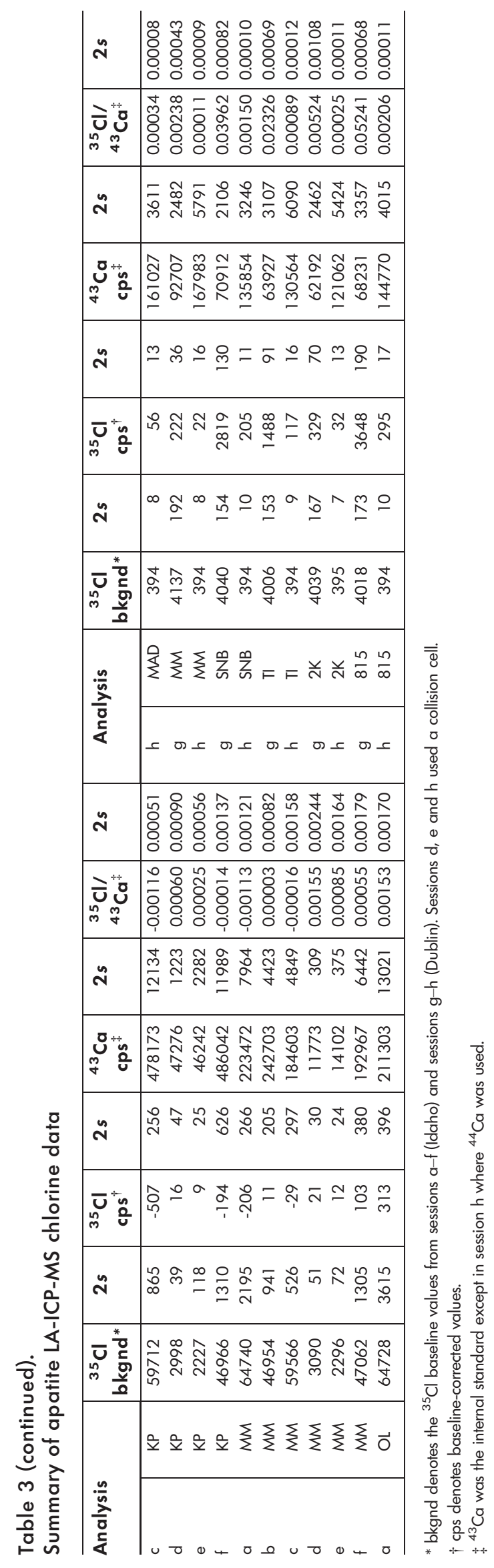

cases). These data are used to infer a conservative detection limit of $0.05 \% \mathrm{~m} / \mathrm{m}$ for apatite $\mathrm{Cl}$ determinations using the Idaho ICP-MS set-up. No low Cl apatites $(<0.05 \% \mathrm{~m} / \mathrm{m} \mathrm{Cl}$ ) for which there were also EPMA data available were analysed using the Dublin ICP-MS set-up. The detection limit for this laboratory set-up is therefore harder to assess but is likely to be lower given the substantially lower ${ }^{35} \mathrm{Cl}$ backgrounds.

\section{Discussion}

Whereas the use of the collision cells in both analytical set-ups did significantly improve the ${ }^{35} \mathrm{Cl}$ background, it also significantly reduced the sensitivity in the low-mass end of analytes, with no significant improvement in the ${ }^{35} \mathrm{Cl}$ signalto-background ratio. This suggests that the mass 35 signal is not a molecular interference but rather genuine ${ }^{35} \mathrm{Cl}$, most likely in the argon nebuliser gas. The order of magnitude difference in the ${ }^{35} \mathrm{Cl}$ background between the two analytical set-ups is likely to be related to differences in instrument sensitivity and the chlorine concentration in the argon gas supply. The sensitivity of the Agilent $7700 \times$ was better than the iCAP Qc for the low-mass end of the periodic table (Figure 2) and, in particular, was 3.5 times more sensitive on mass 35. However, the sensitivity of the iCAP Qc rose sharply with atomic number with the result that it was over two times more sensitive at the high-mass end of the periodic table (Figure 2). It is estimated that ${ }^{35} \mathrm{Cl}$ content of the argon nebuliser gas was three times higher in the Idaho set-up. The ${ }^{37} \mathrm{Cl}$ signal-to-background ratio was significantly improved by the use of the collision cell suggesting the presence of an interfering molecular species, probably ${ }^{36} \mathrm{ArH}^{+}$. As ${ }^{35} \mathrm{Cl}$ is $~ 3$ times more abundant than ${ }^{37} \mathrm{Cl}$ (the natural ${ }^{35} \mathrm{Cl} /{ }^{37} \mathrm{Cl}$ ratio is $\sim 3.13$ ) and appears devoid of significant molecular interferences, chlorine concentration measurements should employ the ${ }^{35} \mathrm{Cl}$ isotope.

Although the $\mathrm{Cl}$ versus $\mathrm{Ca}$ calibration relationships presented in Figure 1 appear very robust, the dependence of the calibration on the high $\mathrm{Cl}$ apatite samples (the Bamble end-member chlorapatites, B3 and ODE) requires further investigation. The mean change in slope of the calibration relationship in sessions a-f (Idaho) when sample B3 is removed is $2.2 \%$, demonstrating that the calibration relationship remains reliable when the highest $\mathrm{Cl}$ apatite remaining has an intermediate $\mathrm{Cl}$ content (B2, 2.95\% m/m Cl). When the Bamble end-member chlorapatite sample ODE is removed from the calibration line in sessions $\mathrm{g}-\mathrm{h}$ (Dublin), the highest $\mathrm{Cl}$ apatite remaining has a $\mathrm{Cl}$ content of $1.38 \%$ $\mathrm{m} / \mathrm{m}$ (sample 815 ). In standard mode, the slope changed by a mere $0.5 \%$ with an $R^{2}$ value of 0.992 (Figure 1i). Even in collision cell (KED) mode, which was characterised by significantly lower sensitivities, the calibration relationship 

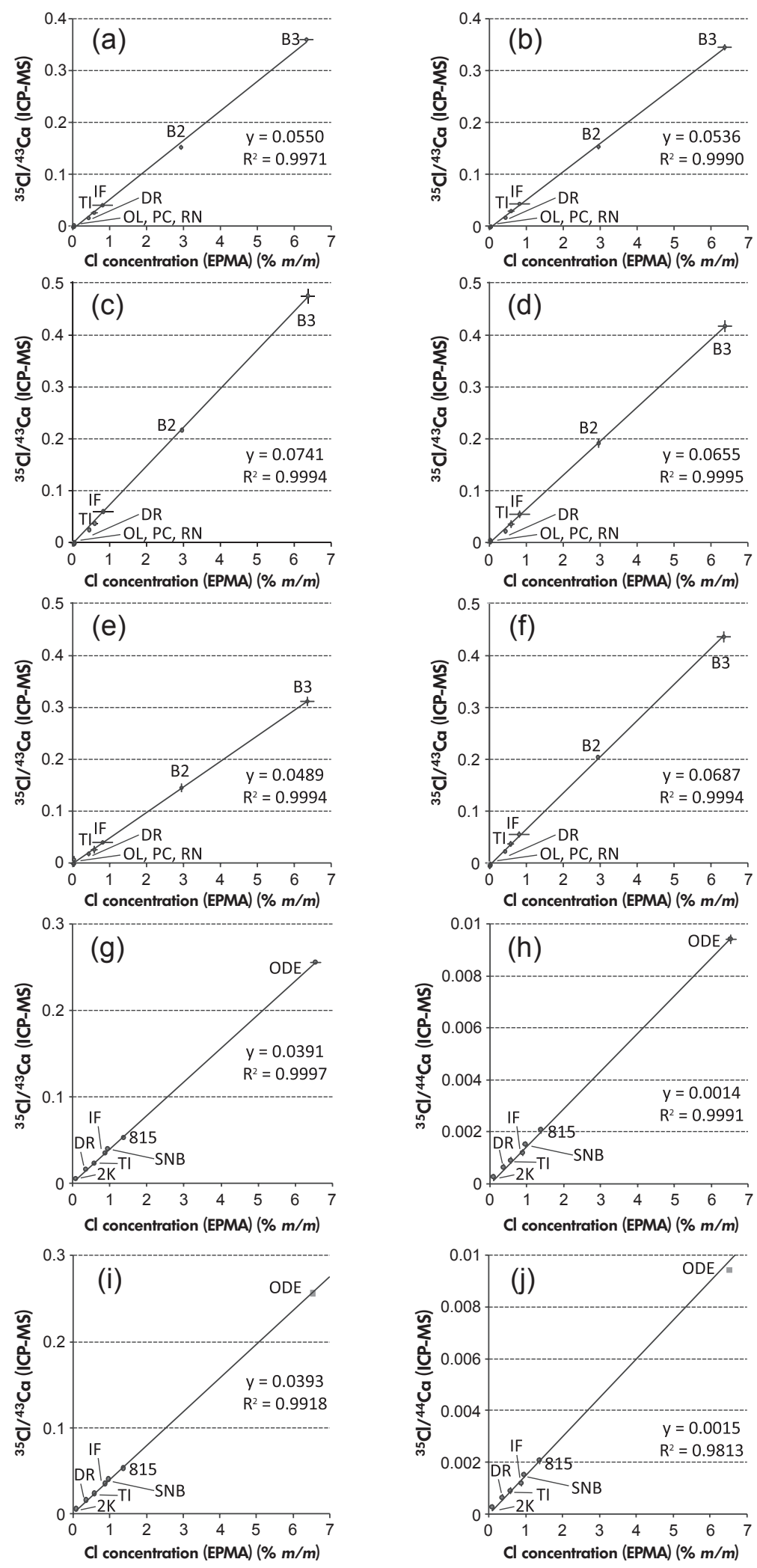

Figure 1. (a-h) ${ }^{35} \mathrm{Cl} /{ }^{43} \mathrm{Ca}$ (or ${ }^{35} \mathrm{Cl} /{ }^{44} \mathrm{Ca}$ ) values plotted against the electron probe microanalysis (EPMA) $\mathrm{Cl}$ concentrations for sessions a-f (Idaho) and sessions $\mathrm{g}-\mathrm{h}$ (Dublin). $(i-i){ }^{35} \mathrm{Cl} /{ }^{43} \mathrm{Ca}$ (or ${ }^{35} \mathrm{Cl} /{ }^{44} \mathrm{Ca}$ ) values plotted against the EPMA Cl concentrations for sessions $g-h$ (Dublin) with the Bamble end-member chlorapatite sample ODE removed from the calibration line (but still illustrated by a grey square). 


\section{GEOSTANDARDS and GEOANALYTICAL \\ RESEARCH}

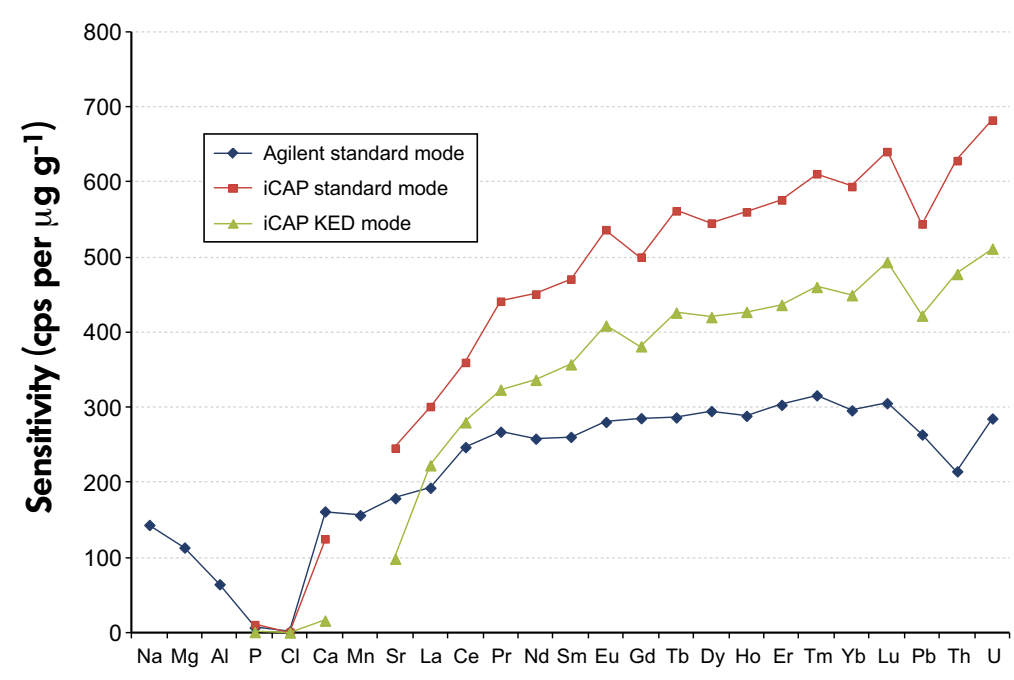

Figure 2. Sensitivity (in cps per $\mu \mathrm{g} \mathrm{g}^{-1}$ ) of the Agilent $7700 \times$ (standard mode) and iCAP Qc (standard and KED modes) for selected elements arranged according to atomic number. The $\mathrm{Cl}$ sensitivity values were calculated using the EPMA Cl contents of the B3 and ODE apatites. The sensitivity of all other elements was calculated using the values of Gao et al. (2002) and Hinton (1999) for the NIST SRM 610 and 612 glass reference materials.

changed by $<4 \%$ with an $R^{2}$ value of 0.981 (Figure 1j). These results demonstrate that although the presence of an intermediate to high $\mathrm{Cl}$ apatite reference material would be preferable when performing apatite $\mathrm{Cl}$ concentration measurements, the $\mathrm{Cl}$ versus $\mathrm{Ca}$ calibration relationships remain robust and well constrained even when using apatite RMs with only low to intermediate $\mathrm{Cl}$ contents.

The size of the laser spot in this study (26 or $30 \mu \mathrm{m}$ ) was chosen as it is sufficiently small to be placed over the vast majority of apatites in grain mount samples yet also sufficiently large that it could yield representative $U$ concentration data for areas counted for fission-track analysis along with simultaneous apatite trace element and U-Pb data. The LA-ICP-MS data employed averages of 10-12 apatite analyses, while the EPMA-derived $\mathrm{Cl}$ concentrations were averages of up to forty analyses. This approach was utilised as several of the apatite samples (e.g., SNB, 2K) exhibit systematic variations in EPMA Cl concentration, which are probably related to magmatic compositional zoning, and hence, a representative pool of ICP-MS analyses (transects on the large megacrysts, individual spot analyses on different megacryst fragments or small euhedral crystals) was used to construct a robust $\mathrm{Cl}$ versus $\mathrm{Ca}$ calibration relationship. Typically, on both analytical set-ups, the dwell time on ${ }^{35} \mathrm{Cl}$ represented $<10 \%$ of the total analysis cycle (Table 2). Significantly increasing the proportion of time spent on the mass 35 peak would enable a substantially smaller spot size (on the order of $10 \mu \mathrm{m}$ ) to be used to investigate fine-scale $\mathrm{Cl}$ zoning, particularly on set-ups with low chlorine backgrounds.

\section{Conclusions}

The halogen content of apatite can be used to determine the initial $\mathrm{F}$ and $\mathrm{Cl}$ concentrations of magmas, while the amount of chlorine in the apatite lattice exerts an important compositional control on the degree of fissiontrack annealing, with apatites richer in fluorine being more easily annealed than those richer in chlorine. LA-ICP-MS is increasingly used in apatite fission-track dating to determine $\mathrm{U}$ concentrations. Simultaneous $\mathrm{Cl}$ concentration measurements can be integrated with U-Pb age information and trace element concentration measurements to yield a very powerful LA-ICP-MS analytical protocol that combines highand low-temperature cooling age data with information on apatite annealing kinetics and the composition of the parent igneous rock type.

Apatite $\mathrm{Cl}$ data were acquired using two analytical setups, both of which used a $193 \mathrm{~nm}$ ArF Excimer laser coupled to a quadrupole ICP-MS. ${ }^{35} \mathrm{Cl}$ backgrounds varied significantly between the two set-ups (45-65 kcps vs. $\sim 4 \mathrm{kcps}$ ), which is thought to be related to differences in instrument sensitivity at the low-mass end of analytes and the ${ }^{35} \mathrm{Cl}$ content of the argon nebuliser gas. The ${ }^{35} \mathrm{Cl}$ signalto-background ratio was not improved by a collision cell on either set-up, demonstrating that the mass 35 peak is not a polyatomic isobaric interference but rather represents ${ }^{35} \mathrm{Cl}$. In contrast, the ${ }^{37} \mathrm{Cl}$ signal-to-background ratio was improved by use of a collision cell, suggesting the presence of a molecular interference (most likely ${ }^{36} \mathrm{ArH}^{+}$). 
The apatite sample suite included nineteen different samples representative of the range likely to be encountered in natural apatites along with extreme compositional variants, including two end-member chlorapatites. Between twenty-six and thirty-nine isotopes were determined in each apatite sample corresponding to a typical analytical protocol for integrated apatite fission-track and U-Pb dating, along with REE and trace element measurements. If multielement data are not required, the relative dwell time on ${ }^{35} \mathrm{Cl}$ per analysis cycle could be substantially increased, which would allow a small $(\sim 10 \mu \mathrm{m})$ laser spot size to be used to investigate fine-scale $\mathrm{Cl}$ zoning. ${ }^{43} \mathrm{Ca}$ was used as an internal standard to account for variations in instrument sensitivity and ablation volume during sessions. The ${ }^{35} \mathrm{Cl} /{ }^{43} \mathrm{Ca}$ or ${ }^{35} \mathrm{Cl} /{ }^{44} \mathrm{Ca}$ values for each apatite (10-20 analyses) when plotted against the EPMA Cl concentrations yield excellently constrained calibration relationships, even when using apatite reference materials with low to intermediate $\mathrm{Cl}$ contents.

\section{Acknowledgements}

Ane Engvik and Aksel Österlöf are thanked for providing the samples of Ødegården apatite and 2K, SNB and 815 apatite, respectively. We also acknowledge Victoria Smith for her assistance in conducting the EPMA. Two anonymous reviewers are thanked for their constructive comments which helped improve the manuscript.

\section{References}

Barbarand J., Carter A., Wood I. and Hurford T. (2003) Compositional and structural control of fission-track annealing in apatite. Chemical Geology, 198, 107-137.

Barfod G.H., Krogstad E.J., Frei R. and Albarède F. (2005)

Lu-Hf and PbSL geochronology of apatites from Proterozoic terranes: A first look at Lu-Hf isotopic closure in metamorphic apatite. Geochimica et Cosmochimica Acta, 69, 1847-1859.

Boyce J.W., Liu Y., Rossman G.R., Guan Y.B., Eiler J.M., Stolper E.M. and Taylor L.A. (2010)

Lunar apatite with terrestrial volatile abundances. Nature, 466, 466-469.

Carlson W.D., Donelick R.A. and Ketcham R.A. (1999)

Variability of apatite fission-track annealing kinetics: I. Experimental results. American Mineralogist, 84, 1213-1223.

\section{Chew D.M. and Donelick R.A. (2012)}

Combined apatite fission track and U-Pb dating by LAICP-MS and future trends in apatite provenance analysis. In: Sylvester P. (ed.), Quantitative mineralogy and microanalysis of sediments and sedimentary rocks.
Short-Course Volume 42. Mineralogical Association of Canada (Québec), 219-248.

Chew D.M., Sylvester P.J. and Tubrett M.N. (2011)

$\mathrm{U}-\mathrm{Pb}$ and Th-Pb dating of apatite by LA-ICP-MS. Chemical Geology, 280, 200-216.

Coulson I.M., Villeneuve M.E., Dipple G.M., Duncan R.A., Russell J.K. and Mortensen J.K. (2002)

Time-scales of assembly and thermal history of a composite felsic pluton: Constraints from the Emerald Lake area, northern Canadian Cordillera, Yukon. Journal of Volcanology and Geothermal Research, 1 14, 331-356.

Donelick R.A. (1993)

A method of fission track analysis utilizing bulk chemical etching of apatite. U.S. Patent Number 5267274.

Donelick R.A., O'Sullivan P.B. and Ketcham R.A. (2005) Apatite fission-track analysis. In: Reiners P.W. and Ehlers T.A. (eds), Low-temperature thermochronology: Techniques, interpretations and applications. Reviews in Mineralogy and Geochemistry, Volume 58. Mineralogical Society of America (Chantilly, VA), 49-94.

Engvik A.K., Golla-Schindler U., Berndt J., Austrheim H. and Putnis A. (2009)

Intragranular replacement of chlorapatite by hydroxy-fluorapatite during metasomatism. Lithos, 112, 236-246.

Fietzke J., Frische M., Hansteen T.H. and Eisenhaver A. (2008)

A simplified procedure for the determination of stable chlorine isotope ratios $\left(\delta^{37} \mathrm{Cl}\right)$ using LA-MC-ICP-MS. Journal of Analytical Atomic Spectrometry, 23, 769-772.

Fleischer R.L., Price P.B. and Walker R.M. (1975) Nuclear tracks in solids: Principles and applications. University of California Press (Berkeley), 605pp.

Gallagher K., Brown R. and Johnson C. (1998) Fission track analysis and its applications to geological problems. Annual Review of Earth and Planetary Sciences, 26, 519-572.

Gao S., Liu X.M., Yuan H.L., Hattendorf B., Günther D., Chen L. and Hu S.H. (2002)

Determination of forty two major and trace elements in USGS and NIST SRM glasses by laser ablation-inductively coupled plasma-mass spectrometry. Geostandards Newsletter: The Journal of Geostandards and Geoanalysis, 26, 181-196.

Gleadow A.J.W. and Duddy I.R. (1981)

A natural long-term track annealing experiment for apatite. NuclearTracks and Radiation Measurements, 5, 169-174.

Gleadow A.J.W., Duddy I.R., Green P.F. and Hegarty K.A. (1986a)

Fission-track lengths in the apatite annealing zone and the interpretation of mixed ages. Earth and Planetary Science Letters, 78, 245-254. 


\section{GEOSTANDARDS and \\ GEOANALYTICAL \\ RESEARCH}

references

Gleadow A.J.W., Duddy I.R., Green P.F. and Lovering J.F. (1986b)

Confined fission-track lengths in apatite - A diagnostic-tool for thermal history analysis. Contributions to Mineralogy and Petrology, 94, 405-415.

Green P.F., Duddy I.R., Gleadow A.J.W., Tingate P.R. and Laslett G.M. (1985)

Fission-track annealing in apatite - Track length measurements and the form of the Arrhenius plot. Nuclear Tracks and Radiation Measurements, 10, 323-328.

Green P.F., Duddy I.R., Gleadow A.J.W., Tingate P.R. and Laslett G.M. (1986)

Thermal annealing of fission tracks in apatite. 1. A

qualitative description. Chemical Geology, 59, 237-253.

Hasebe N., Barbarand J., Jarvis K., Carter A. and Hurford A.J. (2004)

Apatite fission-track chronometry using laser ablation ICPMS. Chemical Geology, 207, 135-145.

Henderson C.E. (2011)

Protocols and piffalls of electron microprobe analysis of apatite. M.Sc. thesis, Geological Sciences, University of Michigan (Ann Arbor)

Hinton R.W. (1999)

NIST SRM 610,61 1 and SRM 612,613 multi-element glasses: Constraints from element abundance ratios measured by microprobe techniques. Geostandards Newsletter: The Journal of Geostandards and Geoanalysis, 23, 197-207.

Laslett G.M., Green P.F., Duddy I.R. and Gleadow A.J.W. (1987)

Thermal annealing of fission tracks in apatite. II: A quantitative analysis. Chemical Geology, 65, 1-3.

Marks M.A.W., Wenzel T., Whitehouse M.J., Loose M., Zack T., Barth M., Worgard L., Krasz V., Eby G.N., Stosnach H. and Markl G. (2012)

The volatile inventory $(\mathrm{F}, \mathrm{Cl}, \mathrm{Br}, \mathrm{S}, \mathrm{C})$ of magmatic apatite: An integrated analytical approach. Chemical Geology, 291, 241-255.

O'Reilly S.Y. and Griffin W.L. (2000)

Apatite in the mantle: implications for metasomatic processes and high heat production in Phanerozoic mantle. Lithos, 53, 217-232.

Paces J.B. and Miller J.D. (1993)

Precise U-Pb ages of Duluth Complex and related mafic intrusions, northeastern Minnesota: Geochronological insights to physical, petrogenetic, paleomagnetic, and tectonomagmatic processes associated with the $1.1 \mathrm{Ga}$ Midcontinent Rift System. Journal of Geophysical Research: Solid Earth, 98(B8), 13997-14013.

Paton C., Hellstrom J., Paul B., Woodhead J. and Hergt J. (2011)

lolite: Freeware for the visualisation and processing of mass spectrometric data. Journal of Analytical Atomic Spectrometry, 26, 2508-2518.

Piccoli P. and Candela P. (1994)

Apatite in felsic rocks - A model for the estimation of initial halogen concentrations in the Bishop Tuff (Long Valley) and Tuolumne Intrusive Suite (Sierra-Nevada Batholith) magmas. American Journal of Science, 294, 92-135.

Piccoli P.M. and Candela P.A. (2002)

Apatite in igneous systems. In: Kohn M.L, Rakovan J. and Hughes J.M. (eds), Phosphates: Geochemical, geobiological and materials importance. Reviews in Mineralogy and Geochemistry, Volume 48. Mineralogical Society of America (Chantilly, VA), 255-292.

Price P.B. and Walker R.M. (1962)

Chemical etching of charged-particle tracks in solids. Journal of Applied Physics, 33, 3407-3412.

Price P.B. and Walker R.M. (1963)

Fossil tracks of charged particles in mica and age of minerals. Journal of Geophysical Research, 68, 4847-4862

Schmitz M.D., Bowring S.A. and Ireland T.R. (2003) Evaluation of Duluth Complex anorthositic series (AS3) zircon as a U-Pb geochronological standard: New highprecision isotope dilution thermal ionization mass spectrometry results. Geochimica et Cosmochimica Acta, 67 3665-3672.

Schoene B. and Bowring S.A. (2006)

$\mathrm{U}-\mathrm{Pb}$ systematics of the McClure Mountain syenite: Thermochronological constraints on the age of the ${ }^{40} \mathrm{Ar} /{ }^{39} \mathrm{Ar}$ standard MMhb. Contributions to Mineralogy and Petrology, 151, 615-630.

Sommerauer J. and Katz-Lehnert K. (1985)

A new partial substitution mechanism of $\mathrm{CO}_{3}{ }^{2-} / \mathrm{CO}_{3} \mathrm{OH}^{3-}$ and $\mathrm{SiO}_{4}{ }^{4-}$ for the $\mathrm{PO}_{4}{ }^{3-}$ group in hydroxyapatite from the Kaiserstuhl Alkaline Complex (SW Germany). Contributions to Mineralogy and Petrology, 91, 360-368.

Stormer J.C., Pierson M.L. and Tacker R.C. (1993) Variation of $\mathrm{F} \mathrm{X}$-ray and $\mathrm{Cl}^{-} \mathrm{X}$-ray intensity due to anisotropic diffusion in apatite during electron-microprobe analysis. American Mineralogist, 78, 641-648.

Tanner S.D., Baranov V.I. and Bandura D.R. (2002) Reaction cells and collision cells for ICP-MS: A tutorial review. Spectrochimica Acta Part B, 57, 1361-1452.

Thomson S.N., Gehrels G.E., Ruiz J. and Buchwaldt R. (2012)

Routine low-damage apatite U-Pb dating using laser ablation-multi-collector-ICP-MS. Geochemistry, Geophysics, Geosystems, 13, doi: 10.1029/201 l gc003928.

\section{Supporting information}

Additional Supporting information may be found in the online version of this article:

Table A1. All apatite LA-ICP-MS chlorine data.

This material is available as part of the online article from: http://onlinelibrary.wiley.com/doi/10.1111/i.1751908X.2013.00246.x/abstract (This link will take you to the article abstract). 